\title{
A Racionalização da Indústria da Reparação Automotiva e a Resistência dos Mecânicos aos Modelos de Competência e de Empreendedorismo
}

\author{
Laura Senna Ferreira
}

\section{INTRODUÇÃO}

$\mathrm{O}$ processo de racionalização da indústria da reparação automotiva, intensificado a partir dos anos 1990, está sujeito a contradições que revelam a diversidade dos interesses, das formas de negócio e de trabalho no setor. No complexo automotivo, a esfera dos serviços tem sido o eixo mais resistente aos processos de racionalização (McIntyre, 1995), o que se deve à pulverização dos estabelecimentos, à dificuldade de padronizar procedimentos, ao fato de o ramo concentrar um grande número de trabalhadores autônomos e de pequenas empresas e, sobretudo, ao "estilo do ofício" do mecânico. O último refere-se a um determinado modo de ser e trabalhar e decorre de uma sociabilidade peculiar, na qual os homens aprendem uma "cultura técnica" e, com esta, uma forma de ser trabalhador que se mostra resistente aos preceitos da eficiência e da produtividade fabril.

A reestruturação da indústria da reparação, por meio da introdução de tecnologias de base microeletrônica e recentes práticas gestoriais, vem trazendo mudanças significativas para o setor, as quais apresentam novas demandas para empresários e trabalhadores em termos de investimentos tecnológicos, conhecimentos e gestão. Além das mudanças no conteúdo e nas formas de organização do trabalho, do ponto de

DADOS - Revista de Ciências Sociais, Rio de Janeiro, vol. 59, no2, 2016, pp. 517 a 551. 
vista dos negócios, os princípios do empreendedorismo chegam ao segmento de modo a transformar os proprietários dos pequenos e médios estabelecimentos de serviços automotivos de "aventureiros" em empreendedores.

A perspectiva dominante dos agentes "reformadores" da indústria da reparação é de que não apenas os proprietários precisam se transformar em empreendedores, mas os próprios trabalhadores devem investir em suas "competências" para manter o estado de "empregabilidade" e melhorar suas qualificações, não apenas técnicas, mas, sobretudo, suas "qualificações sociais".

Tendo como propósito a análise da ofensiva racionalizadora recente na indústria da reparação automotiva, a partir do caso da cidade de Porto Alegre (RS), o presente artigo tem por base entrevistas, inserções etnográficas e investigação documental, ocorridas entre 2010 e 2013. A constituição do grupo investigado não foi aleatória, mas seguiu os critérios da "rede social" da qual os sujeitos fazem parte. Desse modo, a entrada no campo ocorreu a partir de indicações dos mecânicos, sindicatos e entidades relacionadas ao segmento.

No decorrer da pesquisa foram realizadas 56 entrevistas, na sua maioria semiestruturadas: 41 com mecânicos e/ou proprietários de oficinas, em seus locais de trabalho ou residência, e 15 com gestores e membros de entidades vinculadas à indústria da reparação.

A experiência etnográfica foi mais ampla nas oficinas independentes (aquelas que não possuem vínculos com as montadoras), especialmente em 11 delas. Em relação às oficinas concessionárias (aquelas que têm vínculos contratuais com as fábricas de veículos), houve restrições das gerências com respeito ao contato com os mecânicos. Todavia, considerando que os profissionais do setor, ao longo dos seus percursos de trabalho, frequentemente intercalam suas trajetórias entre oficinas concessionárias e oficinas independentes, chegando até mesmo a trabalhar nas duas ao mesmo tempo, os dois locais foram incorporados à investigação sem, contudo, tratá-los de forma dicotômica.

No caso dos mecânicos, o principal critério para a estratificação foi o tempo de permanência na atividade. Dessa maneira, tendo como referência o ano de 1990, período marco da reestruturação da cadeia automotiva, buscou-se abranger no grupo estudado aqueles que começaram na ocupação antes desse momento e aqueles que iniciaram depois. 
A Racionalização da Indústria da Reparação Automotiva e a Resistência...

De modo a abarcar empreendimentos de diferentes portes e estruturas, em termos de equipamentos, condições de trabalho e número de empregados, incluíram-se oficinas independentes situadas nos perímetros mais centrais e outras nas áreas mais periféricas da cidade. Nessa estratificação, excetuaram-se os estabelecimentos informais.

Além das entrevistas e da pesquisa etnográfica, no período de um ano, de julho de 2011 a junho de 2012, investigaram-se as informações e representações sobre a indústria da reparação contidas no Jornal Oficina Brasil, veículo de comunicação de ampla circulação e distribuição gratuita nas mecânicas.

A pesquisa, que foi essencialmente qualitativa, considerou alguns dados estatísticos que envolvem a frota de veículos, bem como oficinas e mecânicos (com base na Relação Anual de Informações Sociais - RAIS Trabalhadores e RAIS Estabelecimentos, de 1985 a 2010), abrangendo os seguintes níveis: municipal (Porto Alegre), estadual (Rio Grande do Sul) e nacional (Brasil).

A análise proposta neste artigo está organizada, basicamente, em três momentos. Em um primeiro instante, apresenta-se o debate teórico que iluminou o estudo. A seguir, estabelece-se uma análise dos processos de racionalização em andamento na indústria da reparação automotiva. Por fim, são examinadas as reformas racionalizantes, indicando-se as formas de resistência dos atores aos princípios do empreendedorismo e do modelo da competência.

\section{A ARGUMENTAÇÃO TEÓRICA}

Na década de 1990, tornaram-se frequentes no Brasil as pressões por flexibilização do mercado de trabalho, por terceirizações, novos métodos de gestão e "produção enxuta" (Ramalho, 2004). Os novos processos trazidos pela reestruturação produtiva são vividos de maneiras distintas pelos diferentes setores, persistindo a "heterogeneidade, a diversidade, os contrastes, a fragmentação" (Sunkel, 2001:291).

Assim, quando a questão é analisada do ponto de vista dos serviços, observa-se que a expansão do terciário é uma das características das mudanças mais recentes no mundo do trabalho (Sorj, 2000). A expansão do setor remete a um conjunto de especificidades vinculadas ao âmbito laborativo. Entre essas, segundo Zarifian (2001), está o fato de a esfera dos serviços ser particularmente impelida a exigir, dos trabalha-

DADOS - Revista de Ciências Sociais, Rio de Janeiro, vol. 59, nº 2, 2016 
dores, atributos cognitivos, atitudes e comportamentos associados ao "modelo da competência".

Em decorrência das transformações em direção às empresas flexibilizadas, a concepção de competência, ligada à ideia de empregabilidade, tem recebido primazia em detrimento da noção de qualificação. Essa última, de acordo com autores como Friedmann (1972), está relacionada a um conjunto de know-how e de "saber-fazer", adquirido no trabalho e na aprendizagem sistemática. Em abordagens mais relativistas, como a de Naville (1975), a qualificação não é reduzida ao conteúdo do trabalho nem às qualidades dos indivíduos, mas vista como resultado de uma relação social e está sujeita a critérios sociais de avaliação (tempo de escolarização, salário, operações de classificação e hierarquia social).

Em linhas gerais, o modelo de qualificação esteve associado ao compromisso fordista, que em boa parte dos países vigorou até os anos 1980, sendo, no contexto de ruptura do pacto fordista, tensionado pelo modelo da competência (Dubar, 1999; Zarifian, 2003). Para Dubar, a ideia de competência remete, entre outros, aos seguintes aspectos: valorização das "qualidades pessoais e relacionais: responsabilidade, autonomia, trabalho em equipe" em detrimento de habilidades técnicas; secundarização da associação entre diplomas e postos de trabalho; abandono dos sistemas de classificação baseados nos níveis de qualificação oriundos das negociações coletivas; ampliação das formas individualizadas de salários e acordos.

O modelo de qualificação, pelo menos na tradição herdada de Naville (1975), é mais coletivo e relacional, enquanto o da competência define-se de forma individualizada. O último, oriundo, sobretudo, do discurso empresarial neoliberal, visa formar virtudes gerais e requisitos culturais mais do que qualificação conteudística. Entre as exigências genéricas das empresas, valorizadas porque podem mudar de acordo com as necessidades do capital (Hirata, 1994), constam: disponibilidade para aprender, capacidade de cooperação, disciplina, princípio da economia do tempo, laboriosidade etc. (Offe, 1990). Essas habilidades, ao lado da escolaridade, são entendidas como garantia de "mentalidade flexível" (Paiva, 1991) de um trabalhador que não somente "sabefazer", mas "sabe-ser" (Boltanski e Chiapello, 2009), sendo encorajado a pensar-se não apenas como força de trabalho, mas como empreendedor de si mesmo (Gomes, 2002). Desta feita, o arquétipo do empre- 
A Racionalização da Indústria da Reparação Automotiva e a Resistência...

endedorismo torna-se, ao lado do modelo da competência, um ideário apropriado a um mercado instável e competitivo.

Nessa conjuntura, a modalidade de negócio definido como "por conta própria" tem sido destacada, sendo foco de duas interpretações: por um lado, é vista como o suprassumo do empreendedorismo (expressão de iniciativa e dinamismo individual) e, por outro, como o ponto mais alto da precarização - trabalhadores vulneráveis em termos de rendimento, direitos e benefícios sociais, porque sem a proteção derivada do estatuto de assalariado, submetidos ao "empreendedorismo por necessidade" (Lima, 2010:174). Um debate semelhante tem se estabelecido com respeito às pequenas empresas. A decisão de montar o próprio negócio ora é encarada como resultado da precarização, ora como projeto de mobilidade social via empreendedorismo.

Nos anos recentes, tem crescido o poder de influência do empreendedorismo enquanto horizonte prático e ideológico, que aposta nas iniciativas individuais como caminho para o próprio sucesso (Nunes, 2009). A perspectiva tem se colocado de modo a encorajar os donos de negócios a vencerem nos mercados, bem como a fazer com que os trabalhadores venham "a perceberem-se a si mesmos como empreendedores e a tratarem seus empregadores como clientes de seus serviços" (Sorj, 2000:32).

Com o processo de reconversão produtiva e a percepção de que as habilidades podem ser descartadas e os empregos perdidos, consolida-se a ideia de que é preciso investir em si mesmo e gerir seu próprio capital humano (Boltanski e Chiapello, 2009). Desse modo, difunde-se a concepção de que os trabalhadores são responsáveis por obter o próprio emprego e, por isso, devem buscar formação continuada e adaptada ao mercado (Lima, 2010).

A flexibilização dá origem a uma cultura do trabalho marcada pelos valores do capitalismo em rede, que tem o individualismo e os parâmetros do mercado como referenciais para diferentes formas de relações sociais. Com isso "o empreendedor, o trabalhador flexível e mesmo o cooperado tornam-se figuras representativas do 'novo' espírito do capitalismo" (ibidem:189).

Em diferentes momentos e contextos, a razão racionalizadora moderna tem travado uma árdua batalha para controlar os trabalhadores e espoliá-los de seus saberes, estilo de vida e valores, a fim de que ope-

DADOS - Revista de Ciências Sociais, Rio de Janeiro, vol. 59, n² 2, 2016 
rem com as referências do utilitarismo econômico (Thompson, 1998). Não raro, contudo, ideais individualistas e de competitividade esbarram em noções de solidariedade e reciprocidade, muito valorizadas pelos trabalhadores, que delas precisam para continuar ganhando a vida (Chalhoub, 2001).

Nesse particular, os estudos de Thompson (1987) contribuem com a discussão quando indicam que, sob condições históricas reais, não há uma forma de dominação que não enfrente resistência à imposição de determinadas lógicas de vida, trabalho e valores. Na perspectiva do autor, as "experiências" objetivas e subjetivas compartilhadas pelos trabalhadores fazem com que, enquanto classe, eles tendam a se sentir compelidos à rebeldia no momento em que certas necessidades, tradições e valores são ameaçados por "agentes racionalizadores".

Todavia, a recusa ou a aceitação não se apresenta de antemão, mas depende de uma série de contingências. A esse respeito, Chalhoub (2001) afirma que "a intenção de enquadrar, de silenciar, acaba revelando também a resistência, a não conformidade, a luta" (ibidem:53). Trata-se, assim, de uma "mistura indivisível de resignação e revolta" (ibidem:254), a qual indica que os valores veiculados pela classe dominante são assimilados, bem como "lidos' ou interpretados de forma um tanto diferente e até contraditória pelos membros da classe trabalhadora" (ibidem:152).

É à análise de ambivalências e dilemas como esses, a partir do caso da indústria da reparação automotiva e dos mecânicos, que se dedicam as seções deste artigo.

\section{A CONSTITUIÇÃO DA CADEIA AUTOMOTIVA BRASILEIRA}

Desde a década de 1950 a indústria automotiva brasileira tem passado por uma série de transformações, mas foi nos anos 1990 que se deram os primeiros passos para a reestruturação produtiva, com as reformas neoliberais (privatização, liberalização comercial, reforma do Estado etc.), o esgotamento do modelo desenvolvimentista e a incorporação de inovações tecnológicas e organizacionais, como veio a ser a adoção do paradigma toyotista de produção e organização (Ramalho, 2004).

A contar de sua implantação, essa indústria viveu momentos alternados entre estabilidade e crise. Após uma dessas crises, com a finalidade de estimular o consumo e a produção de veículos, em 1992 teve início a 
A Racionalização da Indústria da Reparação Automotiva e a Resistência...

Câmara Setorial da indústria automobilística, que estabeleceu as diretrizes para a modernização do setor. Das negociações resultaram dois Acordos Automotivos (1992 e 1993) e, em 1995, a adoção do Regime Automotivo Brasileiro, que visaram evitar a queda nas vendas implantando medidas tais como redução do preço do veículo (devido à redução da carga tributária - Imposto sobre Produtos Industrializados [IPI] e Imposto sobre Circulação de Mercadorias e Serviços [ICMS]) e incentivos à exportação e financiamentos (Bedê, 1997).

As transformações pelas quais o setor passou nos anos 1990 foram sentidas na esfera da produção, do consumo e nos serviços de reparos. As empresas investiram na renovação da frota de automóveis e lançaram muitas marcas, modelos e designs diferentes. O Brasil acompanhou esse processo de reestruturação e ampliou o acesso à "máquina que mudou o mundo" (Womack et al., 1997:126).

Além das inovações econômicas e políticas nesta cadeia, o próprio automóvel foi alterado. A "aplicação da eletrônica aos sistemas mecâni-

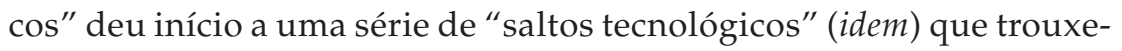
ram impactos para as atividades dos trabalhadores no setor de serviços, esfera que tem se tornado cada vez mais expressiva.

O setor de serviços, a exemplo das concessionárias e centros automotivos, tanto incorpora o que há de mais moderno em termos de tecnologia e gestão do trabalho como permanece, nos pequenos empreendimentos, com a sua face arcaica, a mesma que levou Oliveira (2006:58) a referir-se a esse segmento como expressão da coexistência entre padrões tradicionais e modernos de desenvolvimento na expansão do capitalismo no Brasil.

A respeito do terciário, Salerno afirma que, a partir da década de 1990, junto com o crescimento das vendas de veículos,

cada vez mais o automóvel, assim como vários outros bens, incorpora uma quantidade significativa de serviços [...] o consumidor não compra apenas o veículo, ele compra o veículo e a garantia, a assistência técnica, um serviço de socorro 24 h etc. (1997:515).

Conforme o autor, as próprias fabricantes passam a se interessar pelos serviços dispensados às suas marcas. É justamente nessa conjuntura que se faz crucial entender as atividades e relações que ocorrem na indústria da reparação automotiva.

DADOS - Revista de Ciências Sociais, Rio de Janeiro, vol. 59, n’ 2, 2016 


\section{A FORMAÇÃO DA INDÚSTRIA DA REPARAÇÃO AUTOMOTIVA}

Apesar dos avanços da indústria, no sentido da produção de carros mais confiáveis, ainda requerem-se serviços que resolvam os problemas e desgastes que a intelligentsia automotiva não previu ou não conseguiu evitar. A oficina mecânica, nesse caso, continua sendo o lugar no qual a mais importante tecnologia do século XX revela suas fragilidades.

Tão logo os automóveis começaram a fazer parte da paisagem brasilei$\mathrm{ra}$, as oficinas surgiram no meio rural, em beiras de estrada, nas pequenas e grandes cidades. A ocupação no segmento tornou-se rapidamente sinônimo de profissão para homens pobres da classe trabalhadora, cujo trabalho manual, apesar de exigir uma determinada expertise, não supera o status de atividade inferior. Porém, nos primeiros anos de vida do automóvel na sociedade brasileira,

mecânicos ocupavam uma posição social privilegiada nesse momento. O monopólio do conhecimento que detinham sobre a operação e manutenção dessa nova tecnologia trouxe-lhes não apenas altos salários mecânicos no início do século XX frequentemente possuíam seus próprios carros -, mas uma boa dose de prestígio (Wolfe, 2010:22, tradução livre).

Os primeiros ricos proprietários de veículos comumente contratavam motoristas (chauffeurs) / mecânicos para dirigir seus carros trazidos da Europa (ibidem). Todavia, assim que a indústria começou a produzir automóveis em massa e a baratear seu valor, esses veículos tornaram-se mais acessíveis a outros grupos sociais. Os novos consumidores não podiam pagar por motoristas / mecânicos particulares. Ao mesmo tempo, dirigir o próprio automóvel começava a se tornar fonte de prazer. Como resultado, os motoristas foram relegados cada vez mais a apenas zelar pelos carros. Começou a se delinear, então, um grupo de trabalhadores cuja função específica e em tempo integral era manter e reparar automóveis.

De acordo com Posthuma, a história das oficinas mecânicas está diretamente associada à indústria: "A produção doméstica de peças emergiu no começo do século $[X X]$, e suas raízes remontam aos modestos funileiros de fundo de quintal e aos mecânicos que produziam artesanalmente as peças de reposição para veículos importados" (1997:391). Conforme Sznelwar e Mascia, "oficinas de fundo de quintal foram os 
A Racionalização da Indústria da Reparação Automotiva e a Resistência...

embriões das imensas corporações multinacionais que fabricam automóveis, ônibus e caminhões hoje existentes" (1997:205).

No Brasil, por volta do final da década de 1940, escolas destinadas à formação da força de trabalho começaram a se preocupar com a preparação de trabalhadores para esse mercado. Constituem-se, na ocasião, os primeiros cursos para mecânicos automotivos, que aos poucos foram contribuindo para a demarcação de um campo de trabalho específico.

É esse campo que, nos últimos anos, tem sofrido os impactos das reformas que procuram racionalizar de uma vez por todas as formas de aprendizagem, de trabalho e de negócio na indústria da reparação automotiva.

\section{REESTRUTURAÇÃO DA INDÚSTRIA DA REPARAÇÃO AUTOMOTIVA E DO OFÍCIO DO MECÂNICO}

Na indústria da reparação automotiva, o reconhecimento do valor econômico das atividades de pós-venda (Salerno, 1997) resulta numa ofensiva que visa regulamentar e criar normas de entrada e permanência nesse mercado. As concessionárias, os centros automotivos e as oficinas com maior capacidade de negócios, bem como parte da indústria de autopeças, têm pressionado pela regulamentação da ocupação e por um maior controle com respeito à abertura de novos estabelecimentos.

Ao longo dos últimos anos, as mudanças na cadeia automotiva e as políticas econômicas de incentivo ao setor têm provocado um crescimento da frota veicular brasileira (Anfavea - Associação Nacional dos Fabricantes de Veículos Automotores, Relatório Anual 2012), bem como do número de estabelecimentos de manutenção e reparação de veículos (RAIS de 1995 a 2010) e de mecânicos automotivos com vínculos empregatícios (RAIS de 1990 a 2010) ${ }^{1}$.

É nessa conjuntura que são cunhados os "projetos reformadores" em andamento na indústria da reparação, que envolvem ações objetivas e disputas simbólicas. Nesse sentido, o Jornal Oficina Brasil $(J O B)^{2}$, maior e mais influente jornal do segmento de aftermarket automotivo brasileiro, tem um papel fundamental. O jornal trabalha em prol de um "projeto de reforma" cujo mote é fazer do dono da oficina um verdadeiro homem de negócios. Na publicação, o "novo mecânico" é representado como aquele que empresaria seu estabelecimento e/ou a própria

DADOS - Revista de Ciências Sociais, Rio de Janeiro, vol. 59, nº 2, 2016 
carreira, abandonando o "espontaneísmo amador" dos primeiros tempos do setor: "Gestão empresarial eficiente é a fórmula para o sucesso" (JOB, setembro de 2011); “Capacitação técnica: motivos para investir" (JOB, maio de 2012).

Dessa maneira, o $O O B$ contribui para construir a imagem de um mecânico empreendedor e competente. Nas suas edições mensais, para muito além de divulgar produtos e ensinar sobre reparos, apoia e participa de um projeto que se destina a superar as dificuldades de racionalização do eixo dos serviços, que é uma das esferas da cadeia automobilística mais renitente às padronizações normatizadoras.

Entre as iniciativas de racionalização do ramo estão a elaboração de certificações de competência profissional, como a ASE Brasil, que surgiu em 1996 de uma parceria com a ASE (Automotive Service Excellence) dos Estados Unidos. Ainda, o Instituto de Qualidade Automotiva (IQA), criado em 1994, vem certificando profissionais especializados no setor, bem como fornecendo "certificação ambiental", que objetiva verificar a adequação dos estabelecimentos ao gerenciamento de riscos ao meio ambiente, entregando às oficinas certificadas o Selo Verde.

O tema da certificação insere-se nas práticas de ingerência dos "reformadores" na atividade, que podem ser igualmente observadas nas discussões em torno das campanhas pela manutenção preventiva e inspeção veicular. Por meio dessas campanhas, expressam-se as intenções de instituições e empresas interessadas em regular o setor, como é o caso do Grupo de Manutenção Automotiva (GMA) ${ }^{3}$, responsável pela campanha nacional pela manutenção preventiva, denominada "Carro $100 \%$ "4 , que tem recebido o apoio do Departamento Nacional de Trânsito (Denatran) e do Ministério das Cidades.

As referidas campanhas estão diretamente ligadas aos interesses da indústria de autopeças, que têm entre os mecânicos os seus principais clientes. $O$ fato de que a decisão referente à peça de reposição está, principalmente, nas mãos dos mecânicos, coloca-os no centro das atenções das fabricantes de autopeças e dos lojistas. Considerando que " $80 \%$ dos proprietários de veículos preferem o mecânico de confiança para manutenção" (JOB, março de 2012), e que as oficinas independentes são efetivamente "responsáveis pela manutenção de $80 \%$ da frota circulante no país" (JOB, outubro de 2012), a indústria de reposição tem como alvo o mecânico quando o assunto é combater pirataria, divulgar e vender a marca. 
A Racionalização da Indústria da Reparação Automotiva e a Resistência...

A intervenção no segmento da reparação automotiva também ocorre por parte das montadoras, uma vez que percebem que a esfera dos serviços traz implicações para as vendas. Desde 1999 a Central de Inteligência Automotiva (Cinau) realiza a pesquisa Imagem das Montadoras, que deu origem ao índice $\mathrm{RO}$ (Recomendação de Oficina), e constatou que com o RO elevado, as montadoras "ganham importantíssimos aliados em milhares de oficinas independentes em todo o Brasil, compondo um verdadeiro exército de vendedores destes produtos" (JOB, março de 2012). Por isso, elas têm mantido, ao longo dos anos, um canal de comunicação com os mecânicos através do qual fornecem informações técnicas e tentam controlar a atividade.

Os temas em questão - certificação profissional, combate às peças falsificadas, inspeção veicular e manutenção preventiva - expressam assuntos de interesse da sociedade. Ao mesmo tempo, tais proposições exprimem um projeto empresarial das fábricas de autopeças, de empresas de certificação e de parte das oficinas, que veem nessas práticas uma possibilidade de negócio a partir do controle das atividades na esfera dos serviços.

Para legitimar semelhantes ações, conforme indicado a seguir, constroem-se projeções em torno da idealização do que seria uma "oficina moderna" e uma "oficina tradicional".

\section{A DICOTOMIA TRADICIONAL-MODERNO NO "CAMPO DA OFICINA"}

A emergência de uma nova tônica racionalizadora na indústria da reparação automotiva, tendo em vista a produção de outro perfil profissional e empresarial, destaca a necessidade de renovação dos conhecimentos, do aprimoramento tecnológico e da adoção de modelos de gestão eficiente. As instituições influentes no segmento, como os sindicatos, escolas e entidades do Sistema $\mathbf{S}$, vêm elaborando representações que têm em comum a ideia de que o setor não é mais espaço para "curiosos" e "amadores", pois exige, cada vez mais, perícia técnica e conhecimento de gestão.

No corrente cenário, o Sistema S é entidade-chave. Na cidade de Porto Alegre, a Escola de Educação Profissional Senai Automotivo surgiu em 1999 em resposta ao crescimento da frota veicular ${ }^{5}$ e à crescente necessidade de profissionais na reparação, em um contexto no qual, conforme o coordenador pedagógico da entidade, há um "apagão" de mão de obra no setor, quer dizer, uma grande dificuldade de contratar tra-

DADOS - Revista de Ciências Sociais, Rio de Janeiro, vol. 59, nº 2, 2016 
balhadores. As montadoras, que participaram ativamente da criação da escola, têm cada vez mais lhe atribuído o papel de treinamento dos mecânicos concessionários (diretor, Senai Automotivo, 2010).

No Senai Automotivo, além dos cursos de iniciação e de aperfeiçoamento profissional, foi implementado, em 2002, o Curso Técnico de Manutenção Automotiva, com duração de dois anos e estágio de seis meses, realizado durante ou após a conclusão do Ensino Médio. O curso habilita o aluno a tornar-se encarregado técnico, a supervisionar e a assinar como responsável por todas as atividades executadas na oficina.

OServiço Nacional de Aprendizagem Industrial (Senai) é um dos principais atores na difusão da ideia de que a "oficina tradicional" deve dar lugar à "oficina moderna", que seria mais ou menos assim:

Hoje tu entra na oficina, piso pintado, armários bem organizados, algumas oficinas têm ambiente pro cliente ficar na recepção, com televisão, com café... Os caras hoje trabalham com macacão branco. Então tem um perfil diferente hoje. Houve uma evolução pro mecânico, que não dá mais pra ser daquele perfil, sabe, de graxeiro, que usava as mãos cheias de graxa (coordenador pedagógico, Senai Automotivo, 2010).

As mudanças no setor demandam um trabalhador competente: "O mecânico também tem que aprender a falar com o cliente, dar explicações, saber ser educado, andar limpo... Então ele tem que cuidar da aparência dele" (coordenador pedagógico, Senai Automotivo, 2010). O "mecânico moderno" é descrito como o tipo oposto daquele que tinha a oficina repleta de fotografias de mulheres nuas nas paredes, ao "camarada todo engraxado, todo manchado, todo rasgado, tinha um macacão que não lavava há 500 anos" (diretor, Senai Automotivo, 2010).

De modo a responder à necessidade de uma postura mais profissional e empresarial, as instituições de ensino, como o Senai e outras escolas ${ }^{6}$, têm redirecionado seus currículos para uma abordagem não apenas técnica, mas gestorial e comportamental. O foco das escolas tem se dirigido muito mais para a ideia de "competências" (Dubar, 1999; Zarifian, 2003) do que de "qualificações". Em tese, mais do que o "saber-fazer", o que importa são as "qualificações sociais" que mecânicos com maior capacidade comunicativa e organizativa (Offe, 1990; Paiva, 1991) podem oferecer aos seus empregadores e/ou clientes.

Do ponto de vista das empresas e instituições representativas, assevera-se que, nos dias atuais, os preços dos serviços automotivos estão al- 
A Racionalização da Indústria da Reparação Automotiva e a Resistência...

tos e já não se aceita mais que "qualquer zé-ninguém mexa no carro" (coordenador pedagógico, Senai Automotivo, 2010). Nessa abordagem, destaca-se que o ferramental tornou-se mais caro e as exigências técnicas, maiores, retirando do mercado os que não estudaram nem investiram no estabelecimento. Nesse darwinismo econômico e social, espera-se que os aptos possam "se dar bem", enquanto os mais "frágeis" ficarão do lado de fora, pois são considerados "sem potencial" (Dubar, 2005).

No processo de "reformas", presume-se que os mecânicos proprietários de oficinas devem estar atentos a aspectos tais como: controlar as finanças; estipular metas de negócios; investir em equipamentos e treinamentos; realizar as atividades no menor tempo possível; separar a contabilidade da empresa das contas da casa; implementar sistema de cartão de crédito para evitar maus pagadores; afastar o "cliente amigo", entre outros. A respeito do último aspecto, o presidente do Sindicato da Indústria de Reparação de Veículos e Acessórios (Sindirepa-RS) faz a seguinte consideração: "Tu não pode dar preferência pros amigos. Esses amigos, entre aspas, é que acabam com o negócio" (2011).

Apesar das referidas projeções, as distinções entre "casa" e "empresa", amigos e clientes, tempo de trabalho e de lazer ainda não se completaram e, definitivamente, não há razões para considerar essa "incompletude" como resíduo a ser superado pela marcha do progresso, pois não se trata apenas de uma questão de adaptação. No segmento, os negócios e as relações de amizade e familiares se confundem, inserem-se em contextos mais amplos nos quais se articulam "racionalidades diversas" (Cappelin e Giuliani, 1999). Entre essas "racionalidades" inclui-se a possibilidade de ter uma empresa e não considerar a si mesmo um "empreendedor", pelo menos não na acepção vinculada ao conceito de empreendedorismo preponderante nos discursos gestoriais (Lima, 2010; Boltanski e Chiapello, 2009).

A reestruturação da indústria automotiva tem promovido uma estrutura de negócio mais polarizada na esfera dos serviços, na qual se projetam, por um lado, estabelecimentos com melhores condições de investimentos em termos tecnológicos, de formação e práticas de gestão eficiente e, por outro, aqueles que, sem os mesmos recursos, operam no limite do sustentável ou são excluídos devido à escassez dos seus capitais.

DADOS - Revista de Ciências Sociais, Rio de Janeiro, vol. 59, nº 2, 2016 
Contudo, os programas de racionalização, que operam de forma mais substancial nas oficinas independentes maiores e nas concessionárias, onde se diz que "a oficina funciona como uma empresa, não tem perfumaria" (diretor, Senai Automotivo, 2011), veem-se tensionados pelas dinâmicas das terceirizações. Estas recolocam a convivência em rede entre "oficinas tradicionais" e "modernas" de diferentes portes, e suas práticas diferenciadas com relação às formas de contratação, organização, condições de trabalho, entre outras. Nesse sistema, aqueles que não possuem recursos terceirizam os serviços para os que dominam conhecimentos e aparelhagens, a fim de proceder à avaliação e/ou solução das avarias.

As terceirizações - de parte ou de todo o serviço - ocorrem entre oficinas independentes, bem como entre essas e as concessionárias. Assim, muitos estabelecimentos menores mantêm-se ativos:

Aqui na volta, bem pertinho, tem três oficinas. Eles estão trabalhando, mas a grande maioria dos serviços que eles fazem tem que passar por mim... Eu faço aqui, resolvo aqui para eles, cobro um valor bem menor e eles cobram dos clientes deles lá (A. B., 2011)7.

Se há um movimento de concentração de capital e centralização das empresas, o que ocorre mesmo em sistemas de redes flexíveis, essa confluência não significa o fim das oficinas menores, pelo menos não de todas. Mas, de qualquer maneira, realiza-se uma constrição voltada para uma associação subordinada às oficinas que dominam os conhecimentos e as tecnologias demandadas atualmente.

\section{OS PROJETOS DE EMPREENDEDORISMO}

No discurso racionalizador, as diferenças entre os empresários amadores e empreendedores são vinculadas a distinções entre oficinas concessionárias e independentes. As concessionárias são associadas à gestão e às técnicas modernas, e as independentes, às práticas ineficientes e retrógradas 8 .

Na disputa por mercados, as concessionárias buscam sobrepor-se às independentes. Para o gerente-executivo do sindicato patronal dos concessionários, "toda montadora quer manter sua fatia de mercado e até aumentar... Como ela resolveu fazer isso? Dando um serviço que elas chamam de pós-venda. Ela vende e tem que dar um serviço de primeira qualidade para o cara voltar a comprar" (2010). O pós-venda, 
A Racionalização da Indústria da Reparação Automotiva e a Resistência...

diferentemente do que foi alguns anos atrás, deixou de ser "um mal necessário, hoje ajuda no resultado da empresa no total, porque, na realidade, fideliza clientes" (gerente de pós-venda, concessionária, 2011).

No segmento independente, com a finalidade de modernizar e fidelizar o cliente, o sindicato patronal da reparação tem fomentado, junto ao Serviço Brasileiro de Apoio às Micro e Pequenas Empresas (Sebrae), ações que contribuam para dinamizar os negócios. Atendendo a esse propósito, o Sebrae organizou um curso de gestão de oficinas no qual aborda marketing, atendimento, vendas de serviço, formação de preço, controle de estoque etc. (Sebrae, 2006).

Para os membros do sindicato patronal, quando tem como origem o "chão da oficina", o proprietário sabe conduzir o seu negócio, mas "não sabe ser empresário":

\begin{abstract}
A nossa grande dificuldade hoje é fazer com que as pessoas mudem a mentalidade e deixem apenas de ser reparadores de veículo e sejam empresários. O nosso mecânico não se deu conta ainda de que ele tem que ser profissional; o nosso mecânico ainda está naquele estágio do amadorismo. Ele não é um bom empresário, ele não tem conhecimento de gestão empresarial, não busca esse conhecimento. Nós temos que ficar insistindo para eles frequentarem os cursos, nós temos que implorar, se não eles não vêm. É uma questão de mudança de mentalidade. Por exemplo, nessas palestras feitas pelas fábricas, eles não vão se não tiver churrasco (gerente-executivo, Sindirepa-RS, 2011).
\end{abstract}

Os relatos expressam a intenção de fazer do mecânico um profissional competente e um verdadeiro homem de negócios. Pretende-se superar a chamada "falta de" racionalidade empresarial e impor, no lugar, uma noção operacional e pragmática de uso do tempo e de direção das práticas econômicas que, em vez de imersas em relações sociais mais amplas e complexas, como o favor feito a um amigo, indicado anteriormente, estejam orientadas por uma lógica puramente utilitária de eficiência e lucratividade.

No discurso dos empresários e entidades influentes, o esforço pela organização racional da oficina tem tomado como parâmetro os programas tayloristas mesclados com os ideais toyotistas. Contudo, se a efetividade desses modelos não foi perfeita nas fábricas, tem sido menos ainda no caso das oficinas.

DADOS - Revista de Ciências Sociais, Rio de Janeiro, vol. 59, nº 2, 2016 
Os mecânicos perturbam o projeto racionalizante, trazendo à tona o fato de que o segmento dos serviços é o eixo da cadeia automotiva mais resistente à reestruturação. Em grande medida, essa resistência ocorre porque a maioria dos proprietários de oficinas e/ou mecânicos tem origem na classe trabalhadora, a qual, em decorrência da sua "experiência" (Thompson, 1987) peculiar, possui pontos de vista distintos dos ideais instrumentalistas vinculados aos programas de reestruturação.

Apesar do discurso que fragmenta a categoria em mecânico tradicional e mecânico moderno, tal polaridade tem de ser relativizada. A realidade é muito mais complexa, e em vez de um "mecânico-amador" e um "mecânico-profissional" ou uma "oficina-casa" (tradicional) e uma "oficina-empresa" (moderna), o cenário precisa ser lido não a partir de um polo ou outro, mas entre um e outro.

\section{"ESTILO DO OFÍCIO" E O "CAMPO DA OFICINA"}

Argumenta-se que o "estilo do ofício" - isto é, o jeito de ser e trabalhar daqueles que, no "campo da oficina", exercem sua atividade -, é uma das principais razões pelas quais a racionalização da indústria da reparação encontra obstáculos para se concretizar.

O uso da noção de ofício - em vez de profissão, que é a categoria que a sociologia das profissões tem associado, principalmente, às ocupações que demandam ensino superior (Coelho, 1999; Diniz, 2001) - aparece aqui não associada ao trabalho artesanal, apesar de conter elementos artesanais. Trata-se de uma definição contemporânea e mais abrangente de ofício, que diz respeito às ocupações que envolvem elementos tais como: cultura técnica; conjunto de conhecimentos compartilhados; formas identitárias relacionadas à atividade; exercício da função com regularidade por um longo tempo; parte da aprendizagem no próprio trabalho; regras de grupo; o "saber-fazer"; relação com os objetos; sistema de reputações e status; considerações referentes aos critérios de trabalho bem feito - entre outros aspectos que oferecem adesão a uma categoria de trabalhadores manuais.

Na perspectiva dos entrevistados, ser mecânico vai além do domínio de habilidades técnicas, pois envolve uma determinada cultura e "estilo" associado ao "chão da oficina". Por "estilo do ofício" - e na verdade quer-se dizer "os estilos", porque não existe um único - entende-se uma forma específica de trabalho e de vida vinculada a processos particulares de socialização e experiências cotidianas. Trata-se de um con- 
A Racionalização da Indústria da Reparação Automotiva e a Resistência...

junto de características, atitudes, procedimentos e formas de expressão que são próprias do grupo ocupacional. O "estilo", nesse caso, refere-se aos traços relacionados a uma posição, não apenas na divisão sociotécnica do trabalho, mas na vida e nas hierarquias sociais como um todo. A dimensão técnica o compõe, mas não é tudo. "Estilo" diz respeito a um repertório de práticas e discursos que surgem ligados à aprendizagem e ao exercício da ocupação no "chão da oficina", oferecendo aos sujeitos uma série de recursos (econômicos, discursivos e simbólicos) aos quais recorrem para lidar com as situações cotidianas no trabalho e fora dele.

Confrontados com demandas que não dizem respeito à "natureza" do ofício, como, por exemplo, os discursos do empreendedorismo e da competência, os mecânicos redefinem tais determinações nos seus próprios termos. Aquilo que os "reformadores" entendem como a "falta de" eficiência e "amadorismo", por outro prisma é visto como uma forma de "rebeldia" (Thompson, 1998) da classe trabalhadora, baseada em um modo de trabalho e de vida que não se ajusta completamente aos valores das elites dos negócios.

Contrários a esses valores, os mecânicos, não raro, valorizam outras referências: o "saber-fazer", no lugar do "saber falar"; a qualidade do serviço, em vez da aparência; o preço flexível (que pode considerar as condições financeiras dos clientes), ao invés da estipulação da "hora serviço"; a conversa durante o trabalho, em oposição ao silêncio produtivista; o favor, no lugar de práticas exclusivamente mercantis. Tais atributos emergem como formas de negação a comportamentos motivados pela competitividade de mercado, e por meio dessas e outras recusas os trabalhadores entram em conflito com as ações dos agentes da racionalização.

O "campo da oficina" é marcado por particularidades que se transformam em matéria-prima para os processos de negação dos preceitos racionalizantes: formas de apropriação do tempo - o "tempo da oficina", que não é o mesmo do chão de fábrica; o local de trabalho enquanto espaço social de convívio com amigos e familiares; um maior controle do processo de trabalho pelo trabalhador; a sociabilidade masculina; as formas de linguagem; o manuseio das ferramentas; o diálogo com os objetos; a valorização dos "saberes práticos"; o apreço pelos saberes conceituais apenas na medida em que são úteis ao ofício; a irreverência irônica às regras dominantes; a identidade de ofício, entre outras.

DADOS - Revista de Ciências Sociais, Rio de Janeiro, vol. 59, nº 2, 2016 
Os mecânicos, enquanto grupo de afinidade que tem o domínio técnico de uma expertise, sustentam um determinado "estilo(s)" que envolve sociabilidades, formas de expressão do corpo, linguagem, valores, lazer e temas de interesse em comum? .

O vir a ser mecânico, se não é determinado por uma condição de classe, faz com que a maioria dos que ingressam na atividade, mesmo com origens diferenciadas, vivam as mesmas positividades e negatividades associadas à posição de trabalhador manual de origem popular, já que os que estão na função são socialmente reconhecidos como ocupando posições subalternas.

Quando garotos mais escolarizados ou adultos com diplomas de curso técnico e/ou universitário optam pelo ofício, são levados a negociar com as representações negativas associadas à atividade, atributos sociais que vão da noção de rusticidade (do trabalho sujo) à de desonestidade (da prática de tirar vantagem dos clientes).

As modalidades de inserção no ofício, indicadas a seguir, tendem a ser mais um dos fatores que, dada a sua forma variada e descentralizada, dificultam a racionalização da indústria da reparação.

\section{MODOS DE INSERÇÃO E FORMAS DE APRENDIZAGEM DO OFÍCIO}

Para entender as diferentes formas de inserção no ofício de mecânico, foram estabelecidas algumas chaves de compreensão: "ofício como herança", "ofício como alternativa de trabalho" e "ofício como decisão de carreira".

No "ofício como herança" estão incluídos os mecânicos que ingressaram na atividade influenciados pelo pai e/ou outros familiares próximos que trabalhavam na ocupação. Em outras palavras, são aqueles que foram socializados desde a infância no espaço da oficina e, quando meninos, brincaram com os mesmos objetos que seriam seus instrumentos de trabalho.

Na categoria "ofício como alternativa de trabalho" incluíram-se aqueles que começaram a trabalhar nas oficinas desde meninos, parte deles para ajudar no orçamento familiar e/ou porque os pais não queriam que ficassem "perambulando", expostos aos riscos dos "maus caminhos", comumente associados aos bairros populares da cidade. Encaminhar o filho para trabalhar em uma oficina, a fim de protegê-lo das 
A Racionalização da Indústria da Reparação Automotiva e a Resistência...

vulnerabilidades do meio urbano e garantir-lhe uma profissão, foi um raciocínio comum entre os pais desses garotos.

No "ofício como alternativa de trabalho" também se situam, entre os entrevistados, os que eram garçons; funcionários de ferro-velho; donos de mercado; motoboys e até cabeleireiros. Para esses, o ingresso na atividade não se tratou apenas de garantir um emprego, como tinha feito anteriormente, mas de finalmente aprender uma profissão.

Diferentemente das categorias anteriores, o "ofício como decisão de carreira" não é dado pelo "destino" de nascer e crescer dentro de uma família de mecânicos, nem pela necessidade urgente de obtenção de renda, mas sim pela decisão de ingressar no segmento e por considerações referentes às chances de sucesso em termos de carreira e negócio.

Nesse último caso, o ingresso na atividade ocorre quando o trabalhador já não é tão jovem e a escolaridade é, relativamente, elevada. Na categoria estão aqueles que, na cidade de Porto Alegre, estudaram mecânica na Escola Técnica Parobé ou Senai Automotivo, bem como os que têm ensino superior (engenharia mecânica ou automobilística). O trabalho no setor da reparação após as transformações dos automóveis, especialmente com a incorporação da microeletrônica, tem se mostrado promissor para um grupo mais escolarizado que entrevê na oficina um setor para investir.

Às formas distintas de inserção correspondem práticas diferenciadas de aprendizagem. Para os que herdaram o ofício do pai ou procuraram emprego em oficina com o objetivo de aprender uma profissão, os saberes da atividade são, predominantemente, assimilados no exercício direto e prático no espaço de trabalho. Por outro lado, entre aqueles cujo ingresso na ocupação ocorreu por uma "decisão de carreira", é mais frequente a via das instituições formais de ensino.

Na aprendizagem do ofício no "chão da oficina", tem-se uma forma peculiar de relação que vai além da socialização da técnica e oferece lições de masculinidade, valores e orgulho para os meninos. Para esses, não raras vezes a entrada na oficina absorve a maior parte de seu tempo, representando, inclusive, a interrupção dos estudos.

A forma "prática" de aprender é cotidiana, acontece aos poucos "Tudo o que eu sei hoje, eu aprendi olhando, vendo, fazendo" (M. H., 2011) -, secundariza o "teórico puro", privilegiando a "teoria-em-ato" (Dubar, 2009). De acordo com os relatos, até os anos 1990 era difícil, no

DADOS - Revista de Ciências Sociais, Rio de Janeiro, vol. 59, nº 2, 2016 
segmento, encontrar alguém "estudado". Até mesmo os cursos profissionalizantes eram excepcionais, $\mathrm{e}$ "quem se formava no Senai antigamente era doutor" (L. M., 2011).

Aqueles para os quais as instituições de ensino jogaram um papel substancial procuram afirmar a sua autoridade não apenas a partir da habilidade presente "em carne e osso", mas por referências a "direitos fixados no papel" (Sennett, 2009). Eles aludem aos certificados e diplomas que supõem provar suas expertises e competências técnicas e sociais, alegando que os sem escolaridade não estão aptos para os novos tempos do setor:

Nos anos 1990, quando entrou a injeção com a abertura do mercado, eu já tinha um conhecimento técnico... Hoje muito mecânico não entende... A injeção eletrônica vem com informática junto. Hoje tem veículos que têm trinta centrais eletrônicas pra gerenciar o carro... Então, o mecânico que tem quinta série, que hoje muitos ainda têm, ele não vai ter conhecimento de informática, ele não vai ter conhecimento de física, porque a parte de eletricidade é muito forte... Hoje uma oficina, pra fazer a manutenção de carros com mais avanços tecnológicos, tem que ter esse conhecimento e equipamento (A. E., 2011).

As distintas trajetórias de aprendizagem e o acesso diferenciado aos saberes práticos e formais não são vividos sem tensão. A história desse ofício, sobretudo as formas de aprendizagem e construção dos saberes, produziram uma cultura técnica que é a de que não existe uma única metodologia do fazer. As experiências diferenciadas resultam em uma variedade de procedimentos (McIntyre, 1995). O "jeito certo é o jeito que resolve o problema", "se consegue fazer a coisa boa de uma maneira, não tem quem diga que essa maneira está errada" (D. P., 2010). Essa ideia, hegemônica entre os "práticos", que são a grande maioria, serve de parâmetro para as formas de recusa à padronização dos procedimentos que, com frequência, os mais "estudados" tentam implementar.

Comumente, os "práticos" não se opõem à formalização dos saberes, mas também não concordam com a supervalorização dos conhecimentos formais, expressa, por exemplo, na narrativa de um dos interlocutores sobre os mecânicos que emprega:

Os dois que têm o Senai são os dois melhores em tudo. Em algumas áreas eles que dizem "Olha, faz isso aqui", e o outro pessoal vai e faz. Veja bem, tu tem que ter pessoa com o conhecimento bem qualificado, 
A Racionalização da Indústria da Reparação Automotiva e a Resistência...

mas tu não precisa ter uma pessoa tão qualificada pra executar a parte da obra, o obreiro (G. G., 2011).

Nessa abordagem taylorista da distribuição dos afazeres, que também afirma que os empregados "são como extensão dos meus membros" (ibidem), o importante é ter alguém com conhecimento para diagnosticar, "aí tu pode pegar uma pessoa que tenha boa vontade, que tenha a prática, ele vai lá e faz... Só precisa um cabeça" (ibidem).

A entrada dos "estudados" no setor (é o caso do engenheiro mecânico de visão taylorista referido no depoimento anterior) representa, frequentemente, a intensificação de ações racionalizadoras que objetivam padronizar, controlar e exacerbar a divisão do trabalho na oficina. Todavia, a cultura técnica do ofício, que valoriza as formas diversas de conhecer e fazer, mina, em parte, as imposições das reformas que visam estabelecer "centros", sejam de aprendizagem (Senai, por exemplo), centros de negócio (Sebrae, citando caso análogo) ou outras formas de unidades homogêneas.

Para os homens do ofício, o domínio dos "saberes tácitos", bem como de sua transmissão, significa uma forma de controle sobre o próprio trabalho quando dificilmente se estabelece uma divisão extrema entre os que concebem e os que executam. No caso dos empregados, tais capacidades garantem o controle do ritmo de trabalho, que não pode ser simplesmente expropriado pela gerência. No entanto, ao introduzir na oficina a figura do "obreiro", esses domínios são colocados em xeque.

Para a maioria dos mecânicos, sua qualificação técnica é o que realmente importa, e é em torno dela, conforme analisado na próxima seção, que se constitui uma série de relações para além do âmbito do trabalho stricto sensu.

\section{A OFICINA COMO ESPAÇO DE SOCIABILIDADE E DE REDES DE RECIPROCIDADE}

Para muitos dos homens, atraídos pelo fascínio da tecnologia automotiva, a oficina significa algo mais do que uma fonte de renda: "A minha vida foi isso" (E. S., 2011). Esse é o lugar onde se reparam carros, mas também pode ser, no caso das independentes, o local onde os filhos são criados, onde se convive com a esposa e se encontra os amigos, o que faz da oficina um espaço de sociabilidade.

A própria rotina desses lugares facilita essa imbricação, posto que a atividade permite uma flexibilidade na organização do tempo que con-

DADOS - Revista de Ciências Sociais, Rio de Janeiro, vol. 59, nº 2, 2016 
vém à sociabilidade, com pausas, morosidades e intervalos. Mesmo nas concessionárias e centros automotivos, nas quais a dinâmica é mais acelerada e disciplinada, ainda assim é possível fazer outras coisas durante o trabalho, como ler jornal, conversar com clientes, "trocar uma ideia" com os colegas e assim por diante. A oficina, muitas vezes, é o local de um almoço em grupo, uma roda de chimarrão e demais interações dos mecânicos, e mesmo entre esses e os clientes.

Nesse "campo", o automobilismo opera como espaço que indica tal entrelaçamento entre trabalho, lazer e sociabilidades. Os relatos apresentam o esporte como lugar de negócio, mas também de redes de amizade entre os "preparadores", que estabelecem contato e trocas de conhecimento que servem tanto para as finalidades do automobilismo como para os serviços automotivos de modo geral.

O cotidiano da oficina com relação à busca de informações sobre diagnósticos, defeitos e maneiras de resolver problemas ocorre, em grande medida, de modo informal. Acontece no circuito de saberes presentes na própria base, na qual opera uma rede dinâmica de trocas de conhecimento e ferramental que passa pelas relações de afinidade e camaradagem: "A gente conversa entre a gente, eu tenho vários amigos que têm oficina. Daí vai passando a informação, um liga pro outro, pergunta: 'Ah, tu já pegou um defeito desses?'. E assim nós vamos trocando ideias" (A. B., 2011).

No segmento, apesar da maior centralização da formação nos anos recentes, a exemplo da criação do Senai Automotivo, as trocas de conhecimento e informações permanecem descentralizadas e se operam baseadas em malhas de pessoalidades, conforme se afirma: "Ninguém trabalha sozinho, tem que ter essa rede de amizade" (L. T., 2011).

Essa espécie de comunidade informal transcende as divisões entre oficinas concessionárias e independentes, dada a circularidade entre os mecânicos, que ora trabalham em concessionária, ora em independente:

Se eu chegar em qualquer concessionária, todas eu tenho um vínculo de amizade muito forte. Muitas vezes a gente troca figurinha, como se diz, e eles não me pagam nada, e quando eles necessitam de serviço, alguma coisa, eu também não cobro nada. Uma mão lava a outra (M. H., 2011).

Esse circuito informal também envolve a troca de ferramentas: "Aí o que a gente faz quando não tem o aparelho? Esse relacionamento que eu tenho, porque trabalhei em concessionária... peço pra algum amigo: 
A Racionalização da Indústria da Reparação Automotiva e a Resistência...

'Tu passa o aparelho para mim no carro tal?'” (O. O., 2011). Ademais, tais práticas são alimentadas pelo fato de que o artifício da terceirização dos serviços concessionários para independentes é cada vez mais usual (gerente-executivo, Sincodiv-RS ${ }^{10}$, 2010). As relações que se dão a partir de proximidades são, portanto, fundamentais para assegurar o fluxo da atividade: "Do jeito que tá hoje os carros, tu tem que trocar ideia. As ferramentas são caríssimas... Então eu sei que aquele cara lá tem a ferramenta, eu empresto, depois pego dele uma outra" (A. A., 2011).

No "campo da oficina" há uma forte valorização da cooperação entre os grupos de afinidades, o que é uma forma de solidariedade entre trabalhadores que dela precisam para garantir a sequência de suas atividades (Chalhoub, 2001). As trocas de informações e ferramentas entre os colegas / amigos são um valor do ofício. Trata-se de aspectos que remetem a uma "economia moral" (Thompson, 1998), protegendo os sujeitos da concorrência pura.

Esses são alguns dos elementos que fazem parte do modo de ser do ofício e que distanciam boa parte dos mecânicos das determinações mais individualistas propagadas por grandes empresários e gestores no setor.

\section{ORGANIZAÇÃO E RELAÇÕES DE TRABALHO NO CONTEXTO DE RACIONALIZAÇÃO DAS OFICINAS}

A forma como o trabalho é organizado dá origem a um uso particular do tempo. $\mathrm{O}$ "tempo da oficina" ocorre em meio às porosidades: intervalos para conversar com colegas e clientes; paradas para fumar um cigarro; interrupções para tomar um chimarrão; sair para buscar um lanche ou tomar um café; ficar na frente da oficina observando o movimento; assistir à televisão ou ouvir uma notícia no rádio; brincadeiras com familiares, vizinhos e/ ou colegas de trabalho; chegar mais tarde e sair mais cedo; não abrir a oficina num dia de semana; reduzir o ritmo para aprender sobre um veículo, entre outras. Esses momentos são reveladores de como se opera o "tempo da oficina", considerado, no argumento reformador, problemático do ponto de vista da eficiência. Não obstante, o que é considerado ineficiência é a combinação, nesse espaço, de outras relações que não as baseadas no "tempo útil" estritamente mercantil. 
Nos anos recentes, uma postura mais empresarial de alguns proprietários (mecânicos ou não) vem tentando controlar esse uso flexível do tempo adotando tecnologias e novas práticas de gestão. Com essa finalidade, parte das concessionárias e oficinas de maior porte atrelaram os rendimentos à produtividade: "No nosso sistema, uma planilha regula o rendimento do mecânico... Tudo o que ele faz é inserido no sistema e aquilo vai acumulando. Quando ele atingir a comissão, ele ganha uma porcentagem" (gerente, centro automotivo, 2011). Contudo, afirma-se, essa forma de pressão nem sempre funciona, pois, para alguns, "pode oferecer a melhor comissão do mundo que ele quer ficar lendo jornal" (T. G., 2010). Com respeito a esse tipo de recusa, o relato de um dos mecânicos oferece elementos importantes:

O pessoal me pressionou para que eu não fizesse tudo tão rápido. Disseram que iam fazer o serviço dar problema... "Se tu fizer nesse tempo, nós teremos que fazer no mesmo tempo porque vai estar na tua ficha." Porque tinha ficha. Tu marcava que pegava o carro tal hora e terminava tal hora... "Tu tem que entrar no nosso ritmo." "Ah, então tá, me dá o ritmo que eu já vou entrar no ritmo de vocês" (S. P., 2010).

Tais artimanhas são maneiras de inviabilizar que a gerência tenha plena consciência de quanto tempo cada tarefa demora para ser completada. A estratégia adotada por algumas concessionárias, no sentido de padronizar o serviço em número de horas e conceder aos mecânicos comissão pelas "horas vendidas"11, tem buscado romper as resistências ao lhes oferecer a possibilidade de aumento de salário na medida em que aceleram o trabalho: "A gente trabalha por comissões e horas vendidas... Então a gente tem que correr... Às vezes até dois carros tu faz ao mesmo tempo" (T. G., 2010). Em alguns casos, o pessoal só para em horário de almoço e segue correndo para somar o maior número de horas que for possível (A. L., 2010). Alguns, inclusive, trabalham tanto que o sindicato dos trabalhadores já começa a se preocupar com problemas de doenças ocupacionais no setor (diretor, Stimepa ${ }^{12}$, 2011).

As concessionárias adaptam métodos da organização científica do trabalho: aceleram o tempo de execução das tarefas, modificam o layout da oficina de modo a otimizar o tempo, estabelecem divisão entre diagnóstico e execução (o diagnóstico ficando a cargo das chefias), impõem procedimentos fixos de reparação, incentivos salariais, uso de uniforme e outras maneiras de reorganizar a oficina de forma semelhante a uma fábrica. 
A Racionalização da Indústria da Reparação Automotiva e a Resistência...

As montadoras têm participado desse processo ao exigir a aquisição, pelos concessionários, de ferramentas e equipamentos que padronizem a atividade, reduzam o tempo de execução do trabalho e a dependência com relação aos mecânicos. O sistema Premium, elaborado pelas montadoras e adotado recentemente por várias concessionárias, representa um esforço pela reestruturação e aumento da produtividade nas oficinas. Por esse sistema, o mecânico torna-se polivalente, recebe salário e comissão sobre a ordem de serviço, que inclui o valor das peças vendidas na reparação. Sobre esse último aspecto, afirma-se:

O mecânico acaba virando um mercenário. Eles querem fazer um maior salário e começam a condenar coisas que estão boas... A empresa está induzindo isso... Tu olha para os caras e eles têm cara de mercenários. Eles só pensam em quanto vai dar a ordem de serviço. É assim o troço. Ele procura um problema... Eles abrem os olhos e já deve aparecer dois cifrões, um em cada olho (A. L., 2011).

Considera-se que depois do sistema Premium,

era muito sofrido. Pegava às $8 \mathrm{~h}$, meio-dia era só comer, não tinha descanso, voltava a trabalhar, e ia até às $22 \mathrm{~h}$. Aí comecei a me aborrecer, eles cortaram o lanche da noite e começaram a encher o saco. Eu peguei e disse: sabe de uma coisa, isso aqui não é mais para mim... Eu não passei a ganhar menos. Só que, assim, eu passei a trabalhar muito mais... Eu chegava mais cansado em casa para ganhar a mesma coisa (A. L., 2010).

Alguns dos mecânicos proprietários, cujos depoimentos estão mais em sintonia com as posturas reformistas, consideram que é preciso controlar o pessoal: "O porco engorda debaixo do olho do dono" (P. V., 2011). Na oficina, se por um lado está claro quem é o "dono" e quem é o "por$\mathrm{CO}^{\prime \prime}$, por outro, quando proprietários, chefias ou empregados são todos mecânicos, há uma ideia de que, desse ponto de vista, é "todo mundo meio igual" (N. S., 2011). Todavia, no período mais recente, com a entrada no setor de empresários de outros ramos e a chegada de engenheiros mecânicos e técnicos em automobilística na posição de chefias, a ideia de "igualdade" já não é a mesma, potencializando os conflitos: "Logo que entrou, foi briga e estresse com todo mundo... 'Não quero ninguém parado'. Ele proibiu o pessoal de ler jornal!" (diretor sindical, Stimepa, 2011).

Embora relações conflituosas entre mecânicos e chefias ocorram quando ambos são "colegas de ofício", elas acontecem de forma mais tensa

DADOS - Revista de Ciências Sociais, Rio de Janeiro, vol. 59, nº 2, 2016 
quando não há nenhuma expertise compartilhada, quando o dono da oficina é somente empresário e o chefe está ali apenas porque tem diploma e/ou foi incumbido da função de controle. Nesses casos, não existe a dimensão do reconhecimento e respeito resultante da cultura técnica comum, imperando somente o vínculo empregatício.

Esses "empresários" - desempregados que investem suas indenizações ou investidores que veem na reparação automotiva um bom negócio - são tratados como aqueles que "não sabem nada e só sabem mandar" (T. G., 2010). Não são muito bem-vistos porque entendem apenas de negócios e "papelada" burocrática, e não conhecem a técnica. De modo geral, os mecânicos não nutrem nenhum tipo de admiração por esses "empresários puros", os quais rompem a simetria entre proprietários e empregados, que apesar das desigualdades são "colegas de ofício" e compartilham histórias de vida e trabalho em muitos aspectos semelhantes.

Nos casos em que os conflitos no trabalho são acirrados, a opção de "pedir as contas" para montar o próprio negócio é uma das saídas a recorrer. Há um fluxo dos que intercalam sua trajetória entre uma oficina e outra, e entre a própria oficina e a do patrão, gerando transtorno em termos de gestão: "Tu acaba tendo que ensinar tudo pro teu mecânico... Quando ele fica bom, daqui a pouco ele já migra pra outra oficina" (chefe de oficina, concessionária, 2011).

A possibilidade de "pedir as contas" é uma das "cartas na manga" dos que não aceitam determinadas condições de trabalho e/ou querem tentar a vida de maneira mais independente. O domínio de uma expertise motiva muitos deles a não trabalhar como empregado e "ser dono do próprio nariz" (A. L., 2010). "Porque a gente trabalha de empregado, mas a intenção é ter o seu próprio negócio" (J. S., 2011).

Os mecânicos abrem negócio próprio, individualmente ou entre amigos, porque há a chance de aumentar o rendimento, mas também para não obedecerem a ordens. Para muitos, deixar de ser empregado é mais importante do que a expectativa de ser um grande empreendedor: "Não quero ficar rico, quero ganhar o meu" (C. P., 2012). Afirma-se que é preciso romper com os vínculos empregatícios, pois

chega um ponto em que a gente tem que trabalhar pra gente. Aí resolvi abrir a oficina aqui... O meu horário sou eu que faço, se eu resolver abrir a oficina eu abro, se eu não resolver abrir eu não abro. Agora no verão, 
A Racionalização da Indústria da Reparação Automotiva e a Resistência...

se eu resolver que não vou trabalhar numa sexta-feira, eu fecho na quinta e abro só na segunda (A. B., 2011).

No segmento da reparação automotiva, em um momento no qual tem havido uma forte mobilização pela racionalização no setor, o ato de "pedir as contas" ou migrar para outra oficina assume um caráter de contestação individual e/ou de grupo.

Os sindicalistas consideram que hoje, nas oficinas maiores, a luta da categoria é o enfrentamento contra a pressão por produtividade que vem acometendo os trabalhadores desde que as oficinas começaram a operar como pit stop de Fórmula 1 (presidente, Federação dos Metalúrgicos-RS, 2011). Em relação a um importante momento desse embate, relata-se:

Nós acabamos com um negócio que tinha lá. Tinha um monte de sinaleira na oficina... Tu pegava tua ordem de serviço, registrava a hora, ia trabalhar, daqui a pouco tu olha lá, tu já tá no amarelo, está terminando o teu tempo. Daqui a pouco tu já entrou no vermelho. Daí acusa no computador e vem um cara e te diz: "Bah, cara, por que tu não terminou isso ainda?” Aí nós acabamos com isso aí... Uma pressão psicológica. Dava muito acidente. $O$ pessoal na correria se cortava, quebrava dedo, mão (diretor, Stimepa, 2010) ${ }^{13}$.

Ante as diferentes facetas do processo de reestruturação analisado, a categoria dos mecânicos é levada a responder às mudanças recusando, negociando e apropriando-se das oportunidades e riscos colocados pelos novos tempos da indústria da reparação automotiva.

\section{CONSIDERAÇÕES FINAIS}

A análise da indústria da reparação automotiva revela que o processo de reconversão produtiva do complexo automobilístico implicou uma série de transformações no setor de serviços. O período é de alterações nas formas de organização do trabalho, nas práticas de gestão e nas tecnologias empregadas nos automóveis e equipamentos de reparo. As oficinas, que até pouco tempo operavam de maneira relativamente autônoma, passaram a sentir mais diretamente a ingerência das montadoras, das fábricas de autopeças, de entidades representativas, entre outros agentes que intervêm nesse mercado com o propósito de transformar os mecânicos em profissionais competentes e empreendedores, e as oficinas em "empresas modernas".

DADOS - Revista de Ciências Sociais, Rio de Janeiro, vol. 59, n² 2, 2016 
Em um cenário de novas configurações produtivas e institucionais, o culto da performance individual passa a ser valorizado, pelos "reformadores", como modelo ideal de conduta na busca por uma subjetividade mais afinada com os ideais de empreendedorismo, de flexibilidade e disposição para estar em formação e atualização permanente. Trata-se de novos direcionamentos que alteraram as percepções e a cultura do ofício.

Todavia, essas não são as únicas formas de ação possíveis no segmento. Do mesmo modo, observa-se que quando a lógica da competitividade parece se impor, as práticas de solidariedade entre os trabalhadores se refazem nas relações horizontalizadas constituídas na base do setor.

O esforço analítico adotado neste estudo indica de que maneira as mudanças estruturais do capitalismo se articulam com as experiências cotidianas dos trabalhadores, que tanto negam como negociam com os postulados da racionalização.

A indústria da reparação automotiva tem se tornado mais heterogênea, com formas mais variadas de ingresso e modelos mais diversos de aprendizagem. O que foi examinado neste artigo ressalta a complexidade do novo contexto, tanto no que tange aos aspectos técnicos da ocupação, como naquilo que diz respeito às sociabilidades que se estabelecem no "chão da oficina" quando a intensificação da gestão por produtividade e o empresariamento das ações tensionam os costumes e valores do ofício.

A discussão apresentada orientou-se pela perspectiva de que no "campo da oficina", onde a divisão de trabalho não é plenamente desenvolvida e cada um, de modo geral, desempenha várias funções, torna-se difícil adaptar os métodos baseados na produção de larga escala, o que mina permanentemente as iniciativas racionalizadoras, que "nunca atingem um êxito total" (Franzoi, 2009).

O ofício do mecânico opera, predominantemente, com base nas trocas, nas experiências e metodologias desenvolvidas pelos próprios trabalhadores, o que resulta em uma cultura ocupacional que tende a renunciar formas de padronização enrijecidas, como aquelas apoiadas nos modelos da competência e do empreendedorismo.

O programa de reestruturação do segmento da reparação passa pela construção ideológica de polaridades - como a dicotomia entre mecânico tradicional e mecânico moderno - que tem como finalidade des- 
A Racionalização da Indústria da Reparação Automotiva e a Resistência...

classificar, em termos técnicos e sociais, alguns dos sujeitos (os supostamente amadores, diletantes e arcaicos) que atuam no ramo, minando, com isso, sua reputação e posição no mercado da reparação.

O processo de racionalização deu um verdadeiro salto com a intensificação da reestruturação da cadeia automotiva. As "reformas", porém, não encontram um campo aberto à sua frente. Elas precisam superar as resistências associadas a um modo de ser e trabalhar próprio ao "estilo do ofício" dos mecânicos, o que não tem sido tarefa fácil.

Parte dessas resistências - manifestas, por exemplo, nas sabotagens, pedidos de demissão e / ou na migração para outra oficina - refere-se a um esforço travado pelos mecânicos para escapar da degradação, mantendo o domínio sobre os seus saberes, suas formas de trabalho e de vida, ao mesmo tempo que ofuscam, no cotidiano, as práticas de dominação. Portanto, não se trata de recusas que ocorrem às cegas, posto que têm por base a realidade objetiva e cultural desses sujeitos, composta por suas inteiras experiências.

Na indústria da reparação, os ideais associados aos modelos de competência e de empreendedorismo são construções que enfrentam obstáculos para se realizar. Na prática, os trabalhadores estão muito mais interessados no conteúdo do trabalho do que no repertório anunciado pelo discurso reformador. Da mesma forma, os mecânicos proprietários, sobretudo no caso das oficinas de menor porte, estão mais focados na parte técnica da atividade do que em ações administrativas altamente empresariais. São características como essas que solapam os projetos reformadores e tensionam os programas de racionalização idealizados para o setor.

(Recebido para publicação em abril de 2014)

(Reapresentado em janeiro de 2015)

(Aprovado para publicação em junho de 2015)

DADOS - Revista de Ciências Sociais, Rio de Janeiro, vol. 59, nº 2, 2016 


\section{Laura Senna Ferreira}

\section{NOTAS}

1. Para mais detalhes estatísticos cf. Ferreira (2013).

2. Ojornal, em operação desde o final dos anos 1980, faz parte do Grupo Germinal, fundado em 1989, que opera ferramentas de marketing direto e mídia segmentada com foco no setor automotivo.

3. O GMA é um fórum de discussão sobre a cadeia de reposição automotiva, criado em 1995 por entidades do aftermarket.

4. Cf. documento oficial da campanha. Disponível em http://carro100.com.br/index.php/dicas-para-o-consumidor/saiba-o-que-e-inspecao-tecnica-veicular.

5. Desde 2004 o Índice de Motorização (veículo a cada 100 habitantes), em Porto Alegre, tem sido crescente: 37,8 (2004); 38,9 (2005); 40,0 (2006); 41,6 (2007); 44,3 (2008); 46,7 (2009); 48,7 (2010); 50,7 (2011); 53,13 (2012) (Detran/RS, 2012).

6. A exemplo do Instituto Profissionalizante Automotivo (Itec) de Porto Alegre, fundado em 1987, que é uma das mais importantes escolas de cursos profissionalizantes da cidade.

7. As iniciais entre parênteses ao longo do artigo referem-se aos nomes dos mecânicos e das oficinas.

8. A esse respeito pode-se conferir a campanha da concessionária Volkswagen composta por duas propagandas televisivas: "Farol desregulado" e "Seta". Disponível em https: / / www.youtube.com/watch?v=qQvIv6WmHpE; https://www.youtube. com/watch?v=O6-5hS3odt4. Acessos em janeiro de 2014.

9. A título de exemplo citam-se, respectivamente, sinais de graxa nas mãos; "gírias de oficina"; apreço pelo "saber-fazer"; gosto pelo automobilismo; atenção aos assuntos associados a automóveis.

10. Sindicato dos Concessionários e Distribuidores de Veículos.

11. A "hora vendida" refere-se à hora tabelada, que determina o tempo que deve ser levado para realizar cada trabalho e o quanto o mecânico irá receber por hora.

12. Sindicato dos Trabalhadores nas Indústrias Metalúrgicas, Mecânicas e de Material Elétrico-Eletrônico da Grande Porto Alegre.

13. O relato do sindicalista indica que a concessionária está empregando elementos da metodologia toyotista de organização do trabalho (Antunes, 2006). 
A Racionalização da Indústria da Reparação Automotiva e a Resistência...

\section{REFERÊNCIAS BIBLIOGRÁFICAS}

ANTUNES, Ricardo. (2006), “A Era da Informatização e a Época da Informalização: Riqueza e Miséria do Trabalho", in R. Antunes (org.), Riqueza e Miséria do Trabalho no Brasil. São Paulo, Boitempo, pp. 15-25.

BEDÊ, Marco Aurélio. (1997), “A Política Automotiva nos Anos 90”, in G. Arbix; M. Zilbovicius (orgs.), De JK a FHC, a Reinvenção dos Carros. São Paulo, Scritta, pp. 357-387.

BOLTANSKI, Luc; CHIAPELLO, Éve. (2009), O Novo Espírito do Capitalismo. São Paulo, WMF Martins Fontes.

CAPPELIN, Paula; GIULIANI, Gian Mario. (1999), “Os Herdeiros: Estudo de Caso das Empresas de Porte Médio da Região Serrana do Estado do Rio de Janeiro", in A. M. Kirschner; E. Gomes (orgs.), Empresa, Empresários e Sociedade. Rio de Janeiro, Sette Letras, pp. 278-300.

CHALHOUB, Sidney. (2001), Trabalho, Lar e Botequim: O Cotidiano dos Trabalhadores do Rio de Janeiro da Belle Époque. Campinas, Unicamp.

COELHO, Edmundo Campos. (1999), As Profissões Imperiais: Medicina, Engenharia e Advocacia no Rio de Janeiro, 1822-1930. Rio de Janeiro/São Paulo, Record.

DINIZ, Marli. (2001), Os Donos do Saber: Profissões e Monopólios Profissionais. Rio de Janeiro, Renavan.

DUBAR, Claude. (1999), "A Sociologia do Trabalho frente à Qualificação e à Competência". Educação e Sociedade, vol. 19, no 64, pp. 87-103.

(2005), A Socialização: Construção das Identidades Sociais e Profissionais. São Paulo, Martins Fontes.

. (2009), A Crise das Identidades: A Interpretação de uma Mutação. São Paulo, Edusp.

FERREIRA, Laura Senna. (2013), Processos de Resistência e Novos Desenhos Identitários: O Ofício do Mecânico e a Racionalização da Indústria da Reparação Automotiva. Tese (Doutorado em Sociologia). Instituto de Filosofia e Ciências Sociais, Universidade Federal do Rio de Janeiro, Rio de Janeiro.

FRANZOI, Naira Lisboa. (2009), “O Conhecimento Informal dos Trabalhadores no Chão de Fábrica”. Educação Unisinos, vol. 13, no 3, pp. 189-200.

FRIEDMANN, Georges. (1972), O Trabalho em Migalhas. São Paulo, Perspectiva.

GOMES, Maria Soledad. (2002), Empregabilidade nos Tempos da Reestruturação e Flexibilização: Trajetórias de Trabalho e Narrativas de Ex-Empregados do Setor Elétrico Brasileiro. Tese (Doutorado em Sociologia). Instituto de Filosofia e Ciências Sociais, Universidade Federal do Rio de Janeiro, Rio de Janeiro.

HIRATA, Helena. (1994), “Da Polarização das Qualificações ao Modelo da Competência”, in C. J. Ferretti et al. (orgs.), Novas Tecnologias, Trabalho e Educação: Um Debate Multidisciplinar. Petrópolis, Vozes, pp. 124-142.

DADOS - Revista de Ciêncius Sociais, Rio de Janeiro, vol. 59, n² 2, 2016 


\section{Laura Senna Ferreira}

LIMA, Jacob Carlos. (2010), "Participação, Empreendedorismo e Autogestão: Uma Nova Cultura do Trabalho?". Sociologias, ano 12, no 25, pp. 158-198.

McINTYRE, Stephen L. (1995), The Repair Man Will Gyp You: Mechanics, Managers, and Customers in the Automobile Repair Industry, 1986-1940. Columbia, University of Missouri-Columbia.

NAVILLE, Pierre. (1975), Teoria da Orientação Profissional. Lisboa, Estampa.

NUNES, Jordão Horta. (2009), Trabalho e Identidade em Ocupações Subalternas". Trabalho apresentado no XI Encontro da Associação Brasileira de Estudos do Trabalho. Campinas, Unicamp, 25 de setembro a 1 de outubro.

OFFE, Claus. (1990), “Sistema Educacional, Sistema Ocupacional e Política da Educação: Contribuição à Determinação das Funções Sociais do Sistema Educacional". Educação e Sociedade, no 35, pp. 9-57.

OLIVEIRA, Francisco. (2006), Crítica à Razão Dualista. São Paulo, Boitempo.

PAIVA, Vanilda. (1991), "Produção e Qualificação para o Trabalho: Uma Revisão da Bibliografia Internacional", in F. C. Dias (org.), Ensino das Humanidades: A Modernidade em Questão. São Paulo, Cortez, Brasília, Seneb, pp. 19-103.

POSTHUMA, Anne. (1997), “Autopeças na Encruzilhada: Modernização Desarticulada e Desnacionalização”, in G. Arbix; M. Zilbovicius (orgs.), De JK a FHC, a Reinvenção dos Carros. São Paulo, Scritta, pp. 389-411.

RAMALHO, José Ricardo. (2004), “Novas Fábricas, Velhas Práticas: Relações Trabalhistas e Sindicais na Indústria Automobilística". Dossiê: Trabalho e Novas Sociabilidades, vol. 17, no 41, pp. 199-210.

SALERNO, Mario. (1997), A Indústria Automobilística na Virada do Século, in G. Arbix; M. Zilbovicius (orgs.), De JK a FHC, a Reinvenção dos Carros. São Paulo, Scritta, pp. 503-522.

SEBRAE (Serviço Brasileiro de Apoio às Micro e Pequenas Empresas (.2006), Reparadoras de Veículos e Oficina Mecânica, in G. Bellaguarda; A. V. Braga (orgs.), Porto Alegre, Sebrae-RS.

SENNETT, Richard. (2009), O Artífice. Rio de Janeiro, Record.

SORJ, Bila. (2000), "Sociologia e Trabalho. Mutações, Encontros e Desencontros". Revista Brasileira de Ciências Sociais, vol. 15, no 43, pp. 25-34.

SUNKEL, Osvaldo. (2001), "A Sustentabilidade do Desenvolvimento na América Latina”, in G. Arbix; M. Zilbovicius; R. Abramovay (orgs.), Razões e Ficções do Desenvolvimento. São Paulo, Unesp/Edusp, pp. 267-310.

SZNELWAR, Laerte; MASCIA, Fausto. (1997), “A Inteligência (Não Reconhecida) do Trabalho", in G. Arbix; M. Zilbovicius (orgs.), De JK a FHC, a Reinvenção dos Carros. São Paulo, Scritta, pp. 205-335.

THOMPSON, Edward Palmer. (1987), A Formação da Classe Operária Inglesa. A Árvore da Liberdade. Rio de Janeiro, Paz e Terra. 
A Racionalização da Indústria da Reparação Automotiva e a Resistência...

. (1998), Costumes em Comum. São Paulo, Companhia das Letras.

WOLFE, Joel. (2010), Auto and Progress: The Brazilian Search for Modernity. New York, Oxford University Press.

WOMACK, James etal. (1997), A Máquina que Mudou o Mundo. Rio de Janeiro, Campus.

ZARIFIAN, Philippe. (2001), “Mutação dos Sistemas Produtivos e Competências Profissionais: A Produção Industrial de Serviço", in M. Salerno (org.), Relações de Serviço: Produção e Avaliação. São Paulo, Senac, pp. 67-93.

. (2003), O Modelo da Competência. Trajetórias Históricas, Desafios Atuais e Propostas. São Paulo, Senac. 


\section{Laura Senna Ferreira}

RESUMO

A Racionalização da Indústria da Reparação Automotiva e a Resistência dos Mecânicos aos Modelos de Competência e de Empreendedorismo

O propósito deste artigo é examinar os processos de racionalização da empresa e do trabalho na indústria da reparação automotiva e as formas de recusa aos mesmos, a partir das práticas de resistência de uma categoria de ofício. Tendo como base um estudo de caso na cidade de Porto Alegre (Brasil), além de entrevistas, etnografia e pesquisa documental, foram analisados os impactos da reestruturação produtiva do complexo automobilístico no setor de serviços de automóveis, a partir dos anos 1990. Observa-se a emergência dos princípios do empreendedorismo e do modelo da competência no campo das oficinas mecânicas, bem como a forma pela qual tais preceitos são contestados pela experiência concreta dos sujeitos.

Palavras-chave: racionalização; resistência; empreendedorismo; competência; indústria da reparação automotiva

\section{ABSTRACT \\ The Rationalization of the Automotive Reparation Industry and the Resistance of Mechanics to Models of Competence and Entrepreneurship}

The purpose of this article is to examine the processes of rationalization of companies and labor in the automotive reparation industry and their repudiation based of practices of resistance carried out by this professional category. Taking into account a study case in the city of Porto Alegre (Brazil), based on interviews, ethnographies and documental research, the article analyzes the impacts of the productive restructuring of the auto-manufacturing complex on the auto-servicing sector, starting in the 1990s. It was possible to observe the emergence of the principles of entrepreneurship and the competence model in the field of auto repair shops, as well as the forms according to which these precepts are contested through the concrete experience of subjects.

Keywords: rationalization; resistance; entrepreneurship; competence; auto repair industry 
A Racionalização da Indústria da Reparação Automotiva e a Resistência...

RÉSUMÉ

La Rationalisation de l'Industrie de la Réparation Automobile et la Résistance des Mécaniciens aux Modèles de Compétence et d'Entreprenariat

L'objectif de cet article est d'analyser les processus de rationalisation des entreprises et du travail dans le secteur de la réparation automobile, ainsi que les formes de leur refus à partir des pratiques de résistance d'une catégorie professionnelle. Sur la base d'une étude de cas menée dans la ville de Porto Alegre (Brésil) et mêlant entretiens, ethnographie et recherche documentaire, nous avons pu analyser, depuis le début des années 1990, les impacts de la restructuration productive du complexe automobile sur le secteur de la réparation. On constate l'émergence des principes de l'entreprenariat et du modèle de la compétence dans les ateliers de réparation, mais également de formes de contestation de ces préceptes au sein de l'expérience concrète des sujets.

Mots-clés: rationalisation; résistance; entreprenariat; compétence; industrie de la réparation automobile

\section{RESUMEN}

La Racionalización de la Industria Automotora y la Resistencia de los Mecánicos al Modelo Competitivo y Emprendedor

El objetivo de este artículo es examinar los procesos de racionalización de la empresa y del trabajo en la industria de reparación automotora, bien como sus formas de rechazo, a través de las prácticas de resistencia de una categoría de oficio. A partir de un estudio de caso en la ciudad de Porto Alegre (Brasil), basado en entrevistas, etnografía e investigación documental, fueron analizados los impactos de la reestructuración productiva del complejo automovilístico en el sector de servicios de automóviles desde los años 1990. Finalmente, se observa y se analiza la emergencia de los principios de la lógica emprendedora y del modelo de competencia en el campo de las oficinas mecánicas, bien como la forma por la cual estos preceptos son contestados por la experiencia concreta de los sujetos.

Palabras clave: racionalización; resistencia; lógica emprendedora; competencia; industria de reparación automotora

DADOS - Revista de Ciências Sociais, Rio de Janeiro, vol. 59, nº 2, 2016 